\title{
Evaluation of the Knowledge of Science Teachers with Didactic Transposition Theory
}

\author{
Fatma Bulut Atalar ${ }^{1}$, Mustafa Ergun ${ }^{2, *}$ \\ ${ }^{1}$ OMÜ Foundation Private Secondary School, Samsun, Turkey \\ ${ }^{2}$ Science Education Department, Faculty of Education, Ondokuz Mayis University, Samsun, Turkey
}

Copyright $\odot 2018$ by authors, all rights reserved. Authors agree that this article remains permanently open access under the terms of the Creative Commons Attribution License 4.0 International License

\begin{abstract}
The quality of the process of teaching is related to the behaviors shown by the teacher and their capability. In cases where teachers who have different training are expected to teach the same topic, teachers may make some alterations in the topics in question. Turkish education system has teachers who have different training but teach the same subject. Transposition is an institutional framework which is concerned with transformation of the knowledge given in schools from its status as didactic scientific knowledge to learned knowledge. The purpose in this study is to determine the factors influential on the process of transformation from knowledge to be taught to knowledge that is taught that are caused by science teachers. In this context, this study was conducted with 5 science teachers with different training and a total of 159 students of these teachers at 7 th grade. Interviews were held with the science teachers and students on the subjects of electron configuration and chemical properties and chemical bonds, and their classes were recorded. As a result of the collected data, it was concluded that the science teachers with different training take the curricula into consideration while transforming the knowledge to be taught, and this transformation was affected by the department they graduated from.
\end{abstract}

Keywords Science Education, Didactic Transposition, Science Teacher, Electron Configuration, Chemical Bonds, Turkey

\section{Introduction}

The quality of the process of learning-teaching is related to the behaviors shown by the teacher and their capability. Qualifications of the teacher are primary factors that affect the efficiency of this process significantly. Turkish education system has different teacher profiles that attend the science courses in middle school. These teachers who are employed in middle schools graduate from the departments of Science Teaching at faculties of education at universities. Additionally, people who have graduated from different departments (physics, chemistry, biology, agriculture, environment, etc.) of different faculties (science, science-letters, engineering, etc.) and have different professions can also work as science teachers in middle schools by getting a field training certificate. For example, current science teachers include those who completed a chemistry degree, received a field training certificate and attend science courses in a middle school. The field knowledge and professional capacity of science teachers who teach the same course are related to not only their individual skills, but also the education and training they received from the department they graduated from. It would not be mistaken to expect that teachers graduated from different departments who teach the same course transfer the information in the curriculum to students in different ways. In this context, this difference in situations may be explained especially by the concept of the didactic, didactic transposition theory and anthropological theory of the didactic [1]. The word didactic corresponds to different meanings in different languages. The word didactic used in this study may be attributed to its meanings in German and French. In French, the noun "didactique" refers to the science that takes the teaching of disciplined knowledge as its subject. The phenomena that are relevant to the didactique of a science are those that pertain to its dissemination $[2,3]$.

Chevallard [4] explained the term Didactic Transposition by starting with studies that are conducted in the field of mathematics teaching [5]. However, today, it has become a theory that is used not only in the field of mathematics, but also in the fields of language, philosophy, social sciences, music, physics teaching, technology, and science [6-21].

In didactic transposition, an object of scholarly knowledge is produced, typically in a research context. It is then selected and rearranged in a societal context to become part of the knowledge to be taught, for example, as part of an official curriculum. It is then again translocated and transformed into the knowledge actually taught in a teaching context, e.g. in a classroom. Finally, it is acquired by learners, becoming learnt knowledge [22]. 


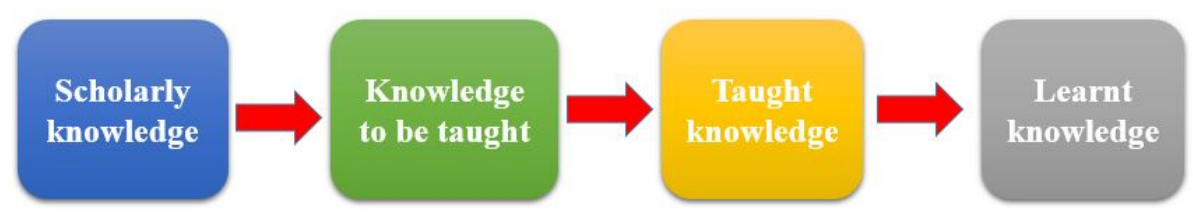

Figure 1. Diagram of the process of didactic transposition [22]

Didactic transposition theory introduces distinctions among: (1) scholarly scientific knowledge, as it is produced by scientists (2) knowledge to be taught officially, as prescribed by the curriculum; (3) knowledge as it is actually taught by teachers in the classroom; and (4) knowledge as it is actually learnt by students. Figure 1 illustrates various steps involved in didactic transposition [22].

The didactic transposition process can be understood as a set of changes that knowledge suffers, the academic sphere (scientific knowledge) of the school environment, in two stages: external (produces the knowledge to be taught) and internal (produces taught to know).

In didactic transposition theory, transpositions related to the teacher are divided into two sections as external and internal transpositions. External didactic transposition is described as "transition from scientific knowledge to knowledge to be taught", while internal didactic transposition is described as "transition from knowledge to be taught to taught knowledge." External didactic transposition covers exposure of the scientific knowledge to various changes during its transition from scientific knowledge to knowledge to be taught. Internal transposition covers all internal effects and transpositions in an education system which turns knowledge to be taught into learnt knowledge.

The Anthropological Theory of the didactic approach developed by Chevallard $[1,23]$ discussed the constituents object, individual, institution and the interrelations among these.

Object: It is denoted by the letter $\mathrm{O}$ and constitutes all there is (tangible and intangible) for at least one person. In this case, anything can be an object: any subject or concept (chemical bond, acid, temperature, heat, cell, and weight), any number (pi), the concept of family, or emotions (excitement and fear).

Individual: It is denoted by the letter $\mathrm{X}$ and every person may be defined as an individual (baby, student, teacher, janitor, school principal).

Institution: It is denoted by the letter I. It is an order which teaches or imposes on its students the ideas and knowledge of itself and has genuine methods and rules (school, religion, science course, family)

In a school environment in general, the object is knowledge, the student or the teacher is the individual, and the classroom, the class or the school is the institution. According to this theory, there are two types of recognizing, knowing something, or in general, an object: personal relation and institutional relation.
When an object $\mathrm{O}$ starts existing for an individual $\mathrm{X}, \mathrm{X}$ recognizes $\mathrm{O}$ and develops a personal recognition towards $\mathrm{O}$. A person's personal recognition of any object is shown as $R(X, O)$ and this states that the individual $X$ recognizes O. In time, personal recognitions of $X$ change and develop, or in clearer words; objects that did not use to exist for X start to exist, and X's personal recognition changes for the objects that already exist [17].

In Anthropological Theory of the Didactic, learning is expressed as the change in the personal recognition of an individual $\mathrm{X}$ for $\mathrm{O}$. This change means the beginning of existence where there is no personal recognition, and development of existence where there is personal recognition. This learning does not change the individual, but their knowledge. In order to talk about learning in the anthropological theory, one should involve institutional relation in this theory.

If any object $\mathrm{O}$ is recognized by any institution $\mathrm{I}$, this $\mathrm{O}$ is an object in I, and the institution I has an institutional relation to the object $\mathrm{O}$ which is shown as $\mathrm{R}(\mathrm{I}, \mathrm{O})$ [17]. When an individual $\mathrm{X}$ enters an institution $\mathrm{I}$, they become an element of the institution I. The personal relation of $X$ who is an element of the institution I to an object $\mathrm{O}$, namely $\mathrm{R}(\mathrm{X}, \mathrm{O})$, will change and develop under the conditions of $R(I, O)$, which is the institutional relation of I to $O$. In this case, learning will occur when the formula $\mathrm{R}(\mathrm{X}, \mathrm{O})$ changes.

It is highly important that new chemistry concepts are taught especially to students at young ages. The responsibilities and duties of teachers increase for chemistry concepts that students cannot materialize by their own experiences. Misconceptions may occur in students as a result of the expression of the teacher, the examples they will provide, drawings and materializations they will make. Concepts related to the subject of chemical bonds constitute the basis of several important chemistry subjects such as especially the structure of matter, physical and chemical change, change of state, chemical reactions, thermodynamics and chemical reactivity [24,25]. Therefore, it is highly important that concepts related to bonds are correctly constructed in the mind of the student [26]. However, chemical bonds and related concepts are not concepts that people can get by their experiences or observations in their environments. It is seen that, as it is not possible for any person to observe the structure of the atom and its relationships with other atoms, in other words, as bonds and related concepts are intangible, students have difficulty in understanding concepts related to chemical bonds [25]. Studies have shown that students have 
misconceptions about chemical bonds and the structure of matter [27-32].

\section{Purpose}

The general objective in this study is to determine the factors that arise from science teachers influential on the process of transforming "knowledge to be taught" into "learnt knowledge" based on didactic transposition theory.

The study consists of the following sub-questions:

1. How is the relationship between the field knowledge of science teachers related to the subjects of electron configuration and chemical bonds and curricula?

2. What is the influence of the departments science teachers graduate from on the transformation of knowledge that occurs on the level of the teacher in the subjects of electron configuration and chemical bonds?

3. Is there an effect of the professional experiences of science teachers on the transformation of knowledge that occurs on the level of the teacher in the subjects of electron configuration and chemical bonds?

For this purpose, the subjects to be investigated were chosen as electron configuration and chemical properties and chemical bonds in the unit structure and properties of matter. The reason for choosing these science subjects as the subjects of study are the following;

The subjects of the atom and chemical bonds are dependent on abstract concepts

There are subjects that are open to misconceptions as students might not be able to construct correct images in these (which may be because of the expressions or drawings of the teacher)

Teachers are obliged to consider restrictions in subject instruction based on the curriculum. The term restriction here refers to taking into consideration the class levels of targeted learning outcomes.

\section{Method}

The model in this study was chosen as the qualitative research method of case study, which is suitable for the problem of the study and the data collection process. A case study is the in-depth analysis and interpretation of one or more events, settings, programs, social groups, communities, individuals or localized systems [33]. The process of qualitative research is a process where different data collection methods such as observation, interview and document analysis are used, and events are presented in their natural environment in a realistic and comprehensive manner [34]. While the qualities that qualitative research techniques should have are discussed in the literature under different titles [35-37], the most frequently encountered qualities are that they encourage sensitivity to the natural environment, the researcher has a participatory role, the study has a comprehensive approach, they facilitate revelation of perceptions, flexibility is provided for the study design, and the analyses are inductive [34].

\subsection{Sample}

The sample of this study consisted of 5 science teachers employed at 4 different middle schools in the central district of a metropolitan province in the Black Sea Region in Turkey, and a total of 159 students in their classes at 7th grade. As seen in Table 1, attention was paid to choose the 5 teachers such that they would have different departments of graduation and levels of experience. Additionally, the average success levels of their schools in the high school placement examinations were also different (Table 2).

Table 1. Information on the Teachers in the Sample

\begin{tabular}{|c|c|c|c|}
\hline $\begin{array}{c}\text { Institution of } \\
\text { Graduation }\end{array}$ & $\begin{array}{c}\text { Department of } \\
\text { Graduation }\end{array}$ & Teacher & $\begin{array}{c}\text { Professional } \\
\text { Experience }\end{array}$ \\
\hline $\begin{array}{c}\text { Institute of } \\
\text { Pedagogy }\end{array}$ & $\begin{array}{c}\text { Physics, Chemistry, } \\
\text { Biology (PCB) }\end{array}$ & T1 & 31 years \\
\hline \multirow{2}{*}{$\begin{array}{c}\text { Faculty of } \\
\text { Science }\end{array}$} & Chemistry & T2 & 17 years \\
\cline { 2 - 4 } & Biology & T3 & 18 years \\
\hline \multirow{2}{*}{$\begin{array}{c}\text { Faculty of } \\
\text { Education }\end{array}$} & Chemistry Education & T4 & 13 years \\
\cline { 2 - 4 } & Science Education & T5 & 9 years \\
\hline
\end{tabular}

The teacher $\mathrm{T} 1$ was employed at the institution S1, which had higher success levels in the high school placement examinations in comparison to the provincial average. The teachers $\mathrm{T} 2$ and $\mathrm{T} 3$ worked at the institution S2, which had higher success levels in comparison to the provincial average. The teacher $\mathrm{T} 4$ worked at the institution S3, which had lower success levels in comparison to the provincial average. The teacher T5 worked at the institution S4, which had mid-level success levels in comparison to the provincial average.

Table 2. Success Levels of the Schools in the Study in Terms of the High School Placement Examinations

\begin{tabular}{|c|c|c|c|}
\hline $\begin{array}{c}\text { Middle } \\
\text { School }\end{array}$ & Teacher & $\begin{array}{c}\text { Success Level of the School } \\
\text { in Comparison to the } \\
\text { Provincial Average }\end{array}$ & $\begin{array}{c}\text { Number of Students } \\
\text { Who Participated in } \\
\text { the Study }\end{array}$ \\
\hline S1 & T1 & high & 31 \\
\hline S2 & T2 & high & 35 \\
\hline S2 & T3 & high & 25 \\
\hline S3 & T4 & low & 38 \\
\hline S4 & T5 & medium & 30 \\
\hline
\end{tabular}

\subsection{Data Collection}

The study was conducted on the subjects of electron configuration and chemical properties and chemical bonds in the middle school science curriculum.

Firstly, the teachers to be included in the study and their classes were determined. As the second stage, the classes 
were recorded on the days and times decided upon with the teachers and 8 class hours of each teacher were observed by the researcher. The lectures were recorded on video. All audio recordings were carried onto the computer environment and transcribed. While the analysis used only the audio recordings, the videos were not analyzed. For each of the observed teachers, the researcher filled out the science teaching field specialty proficiency form prepared by the Turkish Ministry of National Education (MoNE).

At the third stage, the teachers were asked to respond to the interview questions. During the interviews, the teachers were asked how they defined some key concepts chosen from the relevant class subjects (atom, molecule, electron, shell, ion, chemical bond, ionic bond, covalent bond) in a way that is suitable for the level of students. At the end of the class, the researcher applied the questionnaire prepared for the students. This questionnaire consists of six questions. While one of these questions is about the training of the teacher, the others are related to students' evaluation of the teacher's behaviors during class.

This study, while the teachers were analyzed based on transposition theory, used different sources of data as the science curriculum, the science textbook, teacher interview questions, class recordings, student questionnaires and the science teacher field specialty proficiency form (Table 3).

Table 3. Data Collection Tools and Their Purposes

\begin{tabular}{|c|c|c|}
\hline \multicolumn{2}{|c|}{ Data Collection Tools } & Purposes \\
\hline \multicolumn{2}{|c|}{ Science Curriculum } & $\begin{array}{l}\text { The curriculum was examined to learn about } \\
\text { how the subject in question was positioned on } \\
\text { the current curriculum and how much the } \\
\text { teachers had to transfer knowledge. }\end{array}$ \\
\hline \multicolumn{2}{|c|}{$\begin{array}{l}7^{\text {th }} \text { grade Science } \\
\text { textbook }\end{array}$} & $\begin{array}{l}\text { These books were examined to evaluate how } \\
\text { the subject in question is positioned in the } \\
\text { textbooks approved by MoNE and } \\
\text { recommended for students. }\end{array}$ \\
\hline \multicolumn{2}{|c|}{$\begin{array}{l}\text { Teacher Information } \\
\text { Form }\end{array}$} & $\begin{array}{l}\text { This was prepared and applied to determine } \\
\text { the teachers suitable for the study for the } \\
\text { purpose of recording the schedules of the } \\
\text { teachers that taught } 7 \text { th-graders as science } \\
\text { teachers. }\end{array}$ \\
\hline \multirow{2}{*}{$\begin{array}{c}\text { Class } \\
\text { Monitoring }\end{array}$} & $\begin{array}{c}\text { Class } \\
\text { Recordings }\end{array}$ & $\begin{array}{l}\text { Audio recordings were taken by the } \\
\text { researcher with the purpose of determining } \\
\text { how the teachers managed the class and } \\
\text { transferred knowledge to the students. }\end{array}$ \\
\hline & $\begin{array}{l}\text { Observation } \\
\text { Form }\end{array}$ & $\begin{array}{l}\text { This was filled out by the researcher with the } \\
\text { purpose of determining the field specialty } \\
\text { proficiencies of the teachers during the class } \\
\text { based on criteria prepared by MoNE. }\end{array}$ \\
\hline \multicolumn{2}{|c|}{ Student Questionnaire } & $\begin{array}{l}\text { This was prepared and applied with the } \\
\text { purpose of learning about the opinions of the } \\
\text { students of the selected teachers on their } \\
\text { teacher. }\end{array}$ \\
\hline \multicolumn{2}{|c|}{$\begin{array}{c}\text { Teacher Interview } \\
\text { Questions }\end{array}$} & $\begin{array}{l}\text { This was prepared and applied with the } \\
\text { purpose of learning about the details } \\
\text { necessary for the study regarding the science } \\
\text { teachers selected for inclusion. }\end{array}$ \\
\hline
\end{tabular}

\subsection{Data Analysis}

Class monitoring and researcher observation were taken as the basis while analyzing the data in the study. The teacher interview questions and field specialty proficiency ratings were also taken into account while analyzing the responses of the students to the questions in the questionnaire. The analysis used the concepts included in the Anthropological Theory of Didactics approach developed by Chevallard [5]. The concepts adapted to the study in this context are given in Table 4.

According to the table given below the formulae of the relations of the participant teachers to the subject they would teach are given below;

In general $R\left(X_{1}, F\right)$, in specific $R\left(X_{1}, E\right)$ and $R\left(X_{1}, K\right)$ In general $R\left(X_{2}, F\right)$, in specific $R\left(X_{2}, E\right)$ and $R\left(X_{2}, K\right)$ In general $R\left(X_{3}, F\right)$, in specific $R\left(X_{3}, E\right)$ and $R\left(X_{3}, K\right)$ In general $R\left(X_{4}, F\right)$, in specific $R\left(X_{4}, E\right)$ and $R\left(X_{4}, K\right)$ In general $\mathrm{R}\left(\mathrm{X}_{5}, \mathrm{~F}\right)$, in specific $\mathrm{R}\left(\mathrm{X}_{5}, \mathrm{E}\right)$ and $\mathrm{R}\left(\mathrm{X}_{5}, \mathrm{~K}\right)$

Table 4. Anthropological Theory of Didactics Concepts Included in the Study (Object, Individual and Institution)

\begin{tabular}{|c|c|c|c|c|}
\hline Institution & \multicolumn{2}{|c|}{$\begin{array}{l}\text { Individual } \\
\text { (teacher) }\end{array}$} & \multicolumn{2}{|c|}{ Object (subject)) } \\
\hline $\begin{array}{l}\text { School } \\
\text { Code }\end{array}$ & Code & $\begin{array}{l}\text { Type of } \\
\text { Training }\end{array}$ & Code & Subject \\
\hline $\mathrm{I}_{1}$ & $\mathrm{X}_{1}$ & $\mathrm{M}_{1}$ & $\mathrm{~F}$ & Science Education \\
\hline $\mathrm{I}_{2}$ & $\mathrm{X}_{2}$ & $\mathrm{M}_{2}$ & $\mathrm{E}$ & $\begin{array}{c}\text { Electron } \\
\text { Configuration and } \\
\text { Chemical Properties }\end{array}$ \\
\hline $\mathrm{I}_{2}$ & $\mathrm{X}_{3}$ & $\mathrm{M}_{3}$ & K & Chemical Bonds \\
\hline $\mathrm{I}_{3}$ & $\mathrm{X}_{4}$ & $\mathrm{M}_{4}$ & & \\
\hline $\mathrm{I}_{4}$ & $\mathrm{X}_{5}$ & $\mathrm{M}_{5}$ & & \\
\hline
\end{tabular}

F: Science education

E: Electron configuration and chemical properties

$\mathrm{K}$ : Chemical bonds

I: The school which employs the teacher

$\mathrm{X}$ : The teacher

M: The type of the teacher's training

As the subject chosen for the study is in scope of the science course, while the statement $\mathrm{R}\left(\mathrm{X}_{1}, \mathrm{~F}\right)$ was expressed as in general, the statements $\mathrm{R}\left(\mathrm{X}_{1}, \mathrm{E}\right)$ and $\mathrm{R}\left(\mathrm{X}_{1}, \mathrm{~K}\right)$ were expressed as in specific while relating based on the subjects of the relevant topics. Here, the formulae $\mathrm{R}\left(\mathrm{X}_{1}, \mathrm{E}\right)$ and $\mathrm{R}\left(\mathrm{X}_{1}, \mathrm{~K}\right)$ are used to express the relation of the teacher $\mathrm{X}_{1}$ with the subjects of electron configuration and chemical properties and chemical bonds, and the formula $\mathrm{R}\left(\mathrm{X}_{1}, \mathrm{~F}\right)$ is used while making generalizations in science.

The formulae of the schools the participant science teachers worked at and their relation to the subject they taught are given below: 
In general $\mathrm{R}(\mathrm{I} 1, \mathrm{~F})$

In general $\mathrm{R}(\mathrm{I} 2, \mathrm{~F})$

In general $\mathrm{R}(\mathrm{I} 3, \mathrm{~F})$

In general $\mathrm{R}(\mathrm{I} 4, \mathrm{~F})$
The formula R(I1,F) denotes the relation of the teacher coded as X1 to the science education at the institution they work for. The other formulae work the same based on the relation of the institutions to science education. As two of the teachers worked at the same institution, 4 different schools were formulized.

Formulae of the relations of graduated departments for the science teachers;

\begin{tabular}{|l|l|}
\hline In general $\mathrm{R}\left(\mathrm{X}_{1}, \mathrm{M}_{1}\right)$ & \multicolumn{1}{c|}{ The formula $\mathrm{R}\left(\mathrm{X}_{1}, \mathrm{M}_{1}\right)$ denotes the relation of the teacher coded as $\mathrm{X}_{1}$ to } \\
In general $\mathrm{R}\left(\mathrm{X}_{2}, \mathrm{M}_{2}\right)$ & $\begin{array}{l}\text { the department they graduated from. The other formulae work the same } \\
\text { based on the relations of five teachers to the departments they graduated } \\
\text { In general } \mathrm{R}\left(\mathrm{X}_{3}, \mathrm{M}_{3}\right)\end{array}$ \\
from.
\end{tabular}

Formulae of the teacher-school relations based on the relations of the teachers to their science education in general;

\begin{tabular}{|l|r|r|} 
In general $\mathrm{R}\left(\mathrm{X}_{1}, \mathrm{~F}\right) \sim \mathrm{R}\left(\mathrm{I}_{1}, \mathrm{~F}\right)$ & $\begin{array}{c}\text { The formula } \mathrm{R}\left(\mathrm{X}_{1}, \mathrm{~F}\right) \sim \mathrm{R}\left(\mathrm{I}_{1}, \mathrm{~F}\right) \text { describes the compliance between the general } \\
\text { science education of the teacher coded as } \mathrm{X}_{1} \text { and the relation of the institution they }\end{array}$ \\
In general $\mathrm{R}\left(\mathrm{X}_{2}, \mathrm{~F}\right) \sim \mathrm{R}\left(\mathrm{I}_{2}, \mathrm{~F}\right)$ & $\begin{array}{l}\text { ark for to science education. If the level of science education of the teacher is high } \\
\text { In general } \mathrm{R}\left(\mathrm{X}_{3}, \mathrm{~F}\right) \sim \mathrm{R}\left(\mathrm{I}_{3}, \mathrm{~F}\right) \\
\text { In general } \mathrm{R}\left(\mathrm{X}_{4}, \mathrm{~F}\right) \sim \mathrm{R}\left(\mathrm{I}_{4}, \mathrm{~F}\right) \\
\text { and the general level of science education at the institution they work for is also high } \\
\text { In general } \mathrm{R}\left(\mathrm{X}_{5}, \mathrm{~F}\right) \sim \mathrm{R}\left(\mathrm{I}_{4}, \mathrm{~F}\right)\end{array}$ & $\begin{array}{l}\text { the compliance in } \mathrm{R}\left(\mathrm{X}_{1}, \mathrm{~F}\right) \sim \mathrm{R}\left(\mathrm{I}_{1}, \mathrm{~F}\right) \text {. The other formulae also describe the } \\
\text { compliance between the teachers' and their institutions' science education in general. }\end{array}$
\end{tabular}

The observation form that was used in the study was prepared by selecting 18 suitable competency criteria from among 24 criteria described in the science teacher competency document prepared by the Directorate of Training and Education of Teachers, MoNE. For each criterion, performance indicators of $\mathrm{A} 1, \mathrm{~A} 2$, and $\mathrm{A} 3$ were determined. These performance indicators are detailed as the following:

A1 level: This covers the awareness of the teacher in their practices regarding the curriculum and their basic knowledge, skills and attitudes towards the profession of teaching.

A2 level: In addition to the knowledge and awareness of the teacher on A1 level, this covers performance indicators where the teacher applies the curriculum correctly via the experiences they have gained in their practices in the process of instruction, differentiates their practices and considers the interests and needs of students.

A3 level: This covers the performance indicators that necessitates the teacher to differentiate their practices that they improved on A2 level by considering different variables of teaching. A teacher who has performance indicators on this level may contribute to their field by novel practices based on their genuine interpretation, and constantly collaborate with their colleagues, parents of students, civil society organizations and other institutions [38].

\section{Findings}

Considering the explanations to the key concepts asked in the interview form by $\mathrm{T} 1$, who was the most professionally experienced teacher and graduated from $\mathrm{PCB}$, it was found that the teacher used long and complicated statements in their explanations, these statements were higher than the level of the science curriculum, and they contained concepts that cover the subjects taught in a higher grade which would challenge the levels and readiness of students. It was seen that T2 described the same concepts with simple and short sentences. Providing key concepts with such little explanation may create difficulties in understanding of the concepts and comprehension of the subject by students. It was observed that T2 described the concepts they explained in the interview form in a way that was different, shorter and careless than the way they explained them in the classroom. On the other hand, T3 and T5 explained the same concepts in simple sentences, and in suitability with the textbook, student levels and the curriculum. It was understood through in-class observations that $\mathrm{T} 4$ also used simple statements while describing the concepts in question, but they employed terms (non-metal, orbital) and expressions (electrical attraction force) that are not used at 7 th grade for some concepts (covalent bond and shell). As stated by $\mathrm{T} 4$ in the interview form, they found the description of chemistry subjects in the textbook insufficient and transferred the knowledge they had to their students by reducing it. It was found that the concepts provided by $\mathrm{T} 4$ during class were not limited to the textbook, and even on a higher level.

$21 \%$ of T1's students, $68 \%$ of T3's students and $42 \%$ of T4's students responded as 'yes' to the question in the questionnaire "Do you know which department your teacher graduated from?" The response by the students of T2 and T5 was 'no' by $100 \%$. It is understood from this that students had no awareness of what kind of training their teachers had.

The response to the question "Do you think your teacher is explaining the subjects in the class based on your level?" 
was 'yes' by $90 \%$ of T1's students, $96 \%$ of T3's students, $97 \%$ of T5's students, and $100 \%$ of T2's and T4's students. This suggests that students thought their teacher managed the class in a way that is suitable for their levels.

The students were asked the question "Which of the physics, chemistry and biology subjects does your teacher teach better?" T1's students responded as chemistry by $40 \%$, biology by $50 \%$ and physics by $10 \%$. For T2, this was $42 \%$ chemistry, $29 \%$ biology and $29 \%$ physics. For T3, this was $34 \%$ chemistry, $36 \%$ biology and $29 \%$ physics. For T4, this was $36 \%$ chemistry, $34 \%$ biology and $30 \%$ physics. For T5, this was $44 \%$ chemistry, $24 \%$ biology and $32 \%$ physics. Considering the responses in general, it is seen that the teachers were perceived by the students as teaching the subjects better in chemistry by $41 \%$, biology by $33 \%$ and physics by $26 \%$. Considered both in general and individually, it is seen that chemistry subjects were taught better by the teachers.

The responses to the question "In which subjects does your teacher actively include you in the classroom?" were chemistry by $38 \%$, biology by $33 \%$, and physics by $29 \%$. The responses by the students indicate that the teachers included students more actively in chemistry subjects.

The responses to the question "Are your teacher able to comfortably respond to you when you want details of a subject or ask questions?" were 'yes' by $74 \%$ of T1's students, $94 \%$ of T2's students, $92 \%$ of T5's students, and $100 \%$ of T3's and T4's students. In general, the students thought that they received answers to questions they ask of their teachers or obtained detailed information on the subject.

The answers to the question "Is there an additional source you utilize in classes?" were 'yes' by $42 \%$ of T1's students, $51 \%$ of T2's students, $32 \%$ of T3's students, $95 \%$ of T4's students and $23 \%$ of T5's students. The general overview of the cases shows that additional source usage in the classroom varied by teachers. It was observed that usage of additional sources decreased as there were no questions in the high school placement examinations from the subjects in 7th grade and teachers are prohibited from using sources except the textbooks provided by MoNE.

The science teacher competency levels of all the teachers in the sample are given in Table 5. Accordingly, it was observed based on the frequency of the teacher's proficiencies that there were 54 proficiencies at A1 level, 31 proficiencies at $\mathrm{A} 2$ level, only 5 proficiencies at A3 level, and all of these 5 proficiencies belonged to the same teacher.

Table 5. Frequencies of the Science Teacher Competency Levels of the Teachers in the Sample

\begin{tabular}{|c|c|c|c|c|}
\hline $\begin{array}{c}\text { Area of } \\
\text { Proficiency }\end{array}$ & Science Teacher Competency Items & A1 Level & A2 Level & A3 Level \\
\hline \multirow{3}{*}{\begin{tabular}{|c|} 
Planning and \\
Organizing the \\
Learning-Teaching \\
Process
\end{tabular}} & Plans the teaching process suitably for the curriculum & & 4 & 1 \\
\hline & Organizes learning settings in line with the curriculum in the process of teaching & 4 & & 1 \\
\hline & Uses the materials and sources that support the curriculum in the process of teaching & 3 & 2 & \\
\hline \multirow{9}{*}{$\begin{array}{c}\text { Scientific, } \\
\text { Technological and } \\
\text { Social } \\
\text { Development }\end{array}$} & Raises curiosity in students to recognize and examine the environment they live in & 5 & & \\
\hline & Improves the scientific process skills of students & 1 & 4 & \\
\hline & Provides students with an understanding on the issues of the nature and history of science & 3 & 1 & 1 \\
\hline & Improves the critical thinking skills of students & 1 & 4 & \\
\hline & Improves the problem-solving skills of students & 3 & 1 & 1 \\
\hline & $\begin{array}{c}\text { Makes sure that students are able to use scientific and technological concepts correctly and } \\
\text { effectively }\end{array}$ & 1 & 4 & \\
\hline & Makes sure that students make sense of the relationship between science and technology & 2 & 2 & 1 \\
\hline & $\begin{array}{l}\text { Provides students with an understanding on the interactions between scientific and } \\
\text { technological development and the society and the environment }\end{array}$ & 4 & 1 & \\
\hline & Takes the necessary safety precautions in the science and technology teaching environment & 5 & & \\
\hline \multirow{2}{*}{$\begin{array}{l}\text { Monitoring and } \\
\text { Assessing } \\
\text { Development }\end{array}$} & Monitors the development of students & 4 & 1 & \\
\hline & Assesses the data collected by a measurement tool & 3 & 2 & \\
\hline \multirow{4}{*}{$\begin{array}{l}\text { Facilitating } \\
\text { Professional } \\
\text { Development }\end{array}$} & Determines professional proficiencies & 3 & 2 & \\
\hline & Achieves individual and professional development related to science education & 2 & 3 & \\
\hline & Employs scientific research methods and techniques in practices of professional development & 5 & & \\
\hline & Utilizes information technologies for professional development and communication & 5 & & \\
\hline
\end{tabular}




\section{Conclusions}

In scope of the first research question, the relationship between the field knowledge that the teachers had on the subjects of electron configuration and chemical bonds and the content of the curricula was investigated. As a result of the responses by the teachers on the explanation of key concepts of the subject in question in the interviews, it was concluded that the teachers usually explained the concepts in suitability with the curriculum, and the teachers who graduated from the departments of chemistry and chemistry teaching taught these concepts in more detail. As the subjects chosen in the study is in the branch of chemistry, the departments that the teachers in the sample graduated from generally presented compliance between $\mathrm{R}\left(\mathrm{X}_{2}, \mathrm{E}\right), \mathrm{R}\left(\mathrm{X}_{2}, \mathrm{~K}\right)$ and $\mathrm{R}\left(\mathrm{X}_{2}, \mathrm{M}_{2}\right)$, and between $\mathrm{R}\left(\mathrm{X}_{4}, \mathrm{E}\right)$, $\mathrm{R}\left(\mathrm{X}_{4}, \mathrm{~K}\right)$ and $\mathrm{R}\left(\mathrm{X}_{4}, \mathrm{M}_{4}\right)$. While the teachers in the study were seen to rather take the curriculum as a basis while preparing for the class, they preferred the curriculum, the textbook and test books in this order in the process. Student questionnaire results revealed that the subject in question was generally taught by the teachers appropriately for the levels of students. The teachers stated that they considered the targeted outcomes and behaviors included in the curriculum, and they did not have difficulties in transferring these goals and outcomes to the students. It was observed that the subject in question was suitable for 7th-grade students, and while the teachers in the study were careful not to wander off outside the curriculum, they went beyond the curriculum on some occasions for the subject to be understood more clearly. The fact that the national examinations contain only the subjects of 8th grade did not cause any change in the way of teaching the subject for any of the teachers.

Regarding the second research question, the effects of the departments that the teachers graduated from on the transformation of knowledge on the level of the teacher in the subjects of electron configuration and chemical bonds were investigated. According to the results of the student questionnaire, it was understood that the subject in question was taught by the teachers in suitability for the levels of the students, while the teachers who graduated from departments of chemistry and chemistry teaching taught chemistry subject better and included students more actively regarding chemistry subjects among other science subjects. Based on this result, it was concluded that there were differences in the subjects discussed by the teachers based on the departments they graduated from, and they taught the subjects related to their own field in more detail. It was found that the teachers in the study found the textbook insufficient for the subject in question, and the teacher who graduated with a chemistry teaching degree also transferred their own knowledge to students because of the insufficiency of information in the textbook. It is seen that the departments that the teachers graduated from were generally in compliance with $\mathrm{R}\left(\mathrm{X}_{2}, \mathrm{~F}\right) \sim \mathrm{R}\left(\mathrm{M}_{2}, \mathrm{~F}\right)$ and $\mathrm{R}\left(\mathrm{X}_{4}, \mathrm{~F}\right) \sim \mathrm{R}\left(\mathrm{M}_{4}, \mathrm{~F}\right)$ in the science education subjects according to anthropological didactics. This result is in parallel with the results obtained by the other data collection tools. While the relation of the teachers to their institutions was generally in compliance with $R\left(X_{2}, F\right) \sim R\left(I_{2}, F\right)$, it was not in compliance with $\mathrm{R}\left(\mathrm{X}_{4}, \mathrm{~F}\right) \sim \mathrm{R}\left(\mathrm{I}_{4}, \mathrm{~F}\right)$. The reason why it was not in compliance with $\mathrm{R}\left(\mathrm{X}_{4}, \mathrm{~F}\right) \sim \mathrm{R}\left(\mathrm{I}_{4}, \mathrm{~F}\right)$ is believed to be due to other parameters in the study (student level, physical conditions, etc.). Additionally, as the condition $\mathrm{R}\left(\mathrm{X}_{3}, \mathrm{M}_{3}\right)$ affected $\mathrm{R}\left(\mathrm{X}_{3}, \mathrm{~F}\right)$ negatively, $\mathrm{R}\left(\mathrm{X}_{3}, \mathrm{~F}\right) \sim \mathrm{R}\left(\mathrm{M}_{3}, \mathrm{~F}\right)$ and $\mathrm{R}\left(\mathrm{X}_{3}, \mathrm{~F}\right) \sim \mathrm{R}\left(\mathrm{I}_{3}, \mathrm{~F}\right)$ could not be internally compliant.

According to the results obtained by the form filled out by the researcher based on observations towards the same research question, it was seen that the teacher with the highest proficiency was the one who was a graduate of chemistry teaching, while the least proficient teacher was the one who was a graduate of biology. It is believed that the teacher with a chemistry teaching degree had high proficiency because they were a graduate of an education faculty and the subject of the study was chosen from within the branch of chemistry.

Regarding the third problem, the effects of the professional experience of the teachers on the transformation of knowledge on the level of the teacher in the subjects of electron configuration and chemical bond were investigated. It was observed that the teacher with a longer experience in their profession provided more examples that were also suitable for the levels of the students, and they made more repetitions in teaching the subject in question in comparison to the other teachers. It was observed that the teachers with shorter professional experience usually utilized examples in the textbook or on contemporary issues. Most students who participated in the questionnaire preferred young teachers, and as the reason for this, they stated that they felt closer to young teacher, they spoke the same language together, and such teachers are more active and youthful. Those who preferred more experienced teachers thought that such teachers had a better comprehension of the subject as they had more experience. The class monitoring activities of the researcher revealed that the number of years of experience for the teachers did not present an effect on their professional proficiencies that can be noticed clearly, and differences arose from the students, the setting and individual experiences.

\section{Discussion and Recommendations}

Studies where didactic transposition theory was used as the theoretical framework in science education [6-21, 39, 40] have helped several researchers in the analysis of the process of learning-teaching. This study is a study where 
the properties of selected chemistry concepts were revealed under the same theoretical framework. The data obtained in the study were analyzed under three separate contexts.

Firstly, the study found that, while the teachers frequently referred to the curriculum as a basis while preparing the class, they preferred the curriculum, the text book and test books in this order in the process. As stated by Yildırım [35], it is seen that concepts used in the processes of planning and managing classes are restricted primarily by the science curriculum, and then the textbooks. Additionally, the study by Kaya \& Ergun [21] reported that teachers who were employed at different schools and stated that they used the curriculum as a reference reflected their classes in different ways. The data in this study were in line with their results.

Secondly, the proficiency level of the teacher in the study who was a graduate of chemistry teaching was found to be higher in comparison to the others. It is believed that the teacher with a chemistry teaching degree had high proficiency because they were a graduate of an education faculty and the subject of the study was chosen from within the branch of chemistry. While there are studies in the literature which reported that the interpersonal self-efficacy beliefs of science teachers did not change significantly based on variables of gender and city but there were significant differences based on their experience and the institutions that they graduated from [41], these were in parallel to this study. Finally, the class monitoring activities of the researcher revealed that the number of years of experience for the teachers did not present an effect on their professional proficiencies that can be noticed clearly, and differences arose from the students, the setting and individual experiences. Önen and Öztuna [42] investigated the feelings of self-efficacy of science and mathematics teachers working at middle schools based on their professional experience, and it was found that the self-efficacy levels of science teachers based on experience levels were close to each other. The study [43] found that the self-efficacy levels of actively working science and form teachers towards science education did not have significance differences based on their experience levels.

Elaborating on the results obtained in this study, firstly, it may be recommended that this study is repeated in the future with teachers who graduated from different departments. It may be recommended for the Ministry of National Education to provide these teachers who graduated from different departments but teach the same subject and fill these gaps. Additionally, it may be recommended that this study conducted with science subjects is applied in other fields, too.

\section{Acknowledgements}

This study is a part of the first author's master's thesis and this work was supported by OMU-BAP
(PYO.EGF.1904.11.002).

\section{REFERENCES}

[1] Y. Chevallard. Concepts fondamentaux de la didactique: perspectives apportées par une approche anthropologique [Fundamental concepts in didactics: Perspectives provided by an anthropological approach]. Recherches en Didactique des Mathématiques, vol. 12(1), 73-112, 1992.

[2] P. Clément. La recherche en didactique de la biologie [Research in the didactics of biology]. In P. Clément, H.-R. Dahmani \& F. Khammar (Eds.), Didactique de la biologie. Recherches, innovations, formations (pp. 11-28). Blida, Algérie: Ecole Nationale Supérieure de l'Hydraulique, 2000.

[3] M. Artigue \& C. Winslow. International comparative studies on mathematics education: A viewpoint from the anthropological theory of didactics. Recherches en Didactique des Mathematiques, 30(1), 47-82, 2010.

[4] Y. Chevallard. La transposition didactique - Du savoir savant au savoir enseigne [Didactic transposition: From scholarly knowledge to taught knowledge]. Grenoble: La Pensée sauvage, 1985.

[5] Y. Chevallard \& M.-A. Johsua. Un Exemple D'analyse De La Transposition Didactique: La Notion De Distance, Recherche En Didactique Des Mathématiques, 3(2), pp. 157-239, 1982.

[6] M. Abrougui. La génétique humaine dans l'enseignement secondaire en France et en Tunisie. Unpublished Doctorat Thesis, Université Claude Bernard- Lyon I, Lyon, France, 1997.

[7] M. Chatoney. Sciences Technologie à l'école. Etude des pratiques en Technologie. Université de Provence AixMarseille, UFR de Psychologie et Sciences de l'éducation. Unpublished Master thesis, Marseille, France, 1999.

[8] M. Yildırım. Le Concept De Chromosome Dans L'enseignement Génétique En France et En Turquie Dans L'enseignement Sécondaire. Approche Didactique", unpublished master thesis. Université Réné Descartes-Paris 5. Faculté des Sciences Humaines et Sociales- Sorbonne. Paris, France, 2002.

[9] L. Ravel. des programmes a la classe: etude de la transposition didactique interne. exemple de l'arithmétique en terminale $\mathrm{S}$ spécialité mathématique. Unpublised doctorat thesis. Université Joseph Fourier, France, 2003.

[10] S. Özgür. Analyse de la transposition didactique en turquie des institutions noosphériennes à l'enseignant, l'enseignement de la digestion humaine au collège. Unpublished doctorat thesis, Université Joseph Fourier. Grenoble, France, 2004.

[11] F.Ç. Pelitoğlu. İlköğretim 6. sınıf Sindirim Sistemi Konusunun Transpozisyon Didaktik Teorisine Göre İncelenmesi. Unpublished master thesis, Balıkesir Üniversitesi, Fen Bilimleri Enstitüsü, Balıkesir, 2006.

[12] B.T. Khánh Hằng. Une étude didactique de la vie de l'energie dans l'enseignement de la physique, en France et au Vietnam. Des décalages entre savoirs à enseigner au lycée 
et savoirs de la formation universitaire, peuvent-ils être source de difficultés pour les enseignants? Unpublised doctorat thesis. Université Joseph Fourier, France-Université de Pedagogie de Ho Chi Minh Ville Vietnam, 2005.

[13] M.P. Quessada \& P. Clement. Introduction du concept d'évolution humaine buissonnante dans les manuels scolaires de sciences de la vie et de la terre de terminal scientifique, Actes Rencontres de l'ARDIST (Association pour la Recherche en Didactique des Sciences et des Techniques) (pp. 293-300). Lyon: INRP, 2005.

[14] V. Diaz \& A. Poblete. A Model of Professional Competences in Mathematics to Update Mathematical and Didactic Knowledge of Teachers, International Journal of Mathematical Education in Science and Technology, 48(5), 702-714, 2017.

[15] N. M. Gericke, M. Hagberg, V. C. Santos, L.M. Joaquim, C.N. El-Hani. Conceptual Variation or Incoherence? Textbook Discourse on Genes in Six Countries, Science \& Education, 23(2), 381-416, 2014.

[16] P. Maurício, B. Valente, I. Chagas. A Didactic Sequence of Elementary Geometric Optics Informed by History and Philosophy of Science, International Journal of Science and Mathematics Education, 15(3), 527-543, 2017.

[17] P. Frejd \& C. Bergsten. Mathematical modelling as a professional task. Educational Studies in Mathematics, 91(1), $11-35,2016$.

[18] K. Corbett. Gender, identity and culture in learning physics, Cultural Studies of Science Education, 11(2), 371-378, 2016.

[19] D. L. Banegas. Sharing Views of CLIL Lesson Planning in Language Teacher Education, Latin American Journal of Content and Language Integrated Learning, 8(2), 104-130, 2015 .

[20] F. Darnis \& L. Lafont. Cooperative learning and dyadic interactions: two modes of knowledge construction in socio-constructivist settings for team-sport teaching. Physical Education and Sport Pedagogy, 20(5), 459-173, 2015.

[21] G. Kaya \& M. Ergun. An Investigation of the Particulate Nature of Matter Unit according to Didactic Transposition Theory, Elementary Education Online, 11(4), 1101-1120, 2012 .

[22] M. Bosch \& J. Gascon. Twenty-Five Years of Didactic Transposition, ICMI Bulletin, 58, ss. 51-65, 2006.

[23] Y. Chevallard. L'analyse des pratiques enseignantes en anthropologie du didactique. Recherches en Didactique des Mathématiques, vol. 19(2), 221-265, 1999.

[24] S. Ünal. Lise 1 ve Lise 3 Öğrencilerinin Kimyasal Bağlar Konusundaki Kavramları Anlama Seviyelerinin Karşılaştırılması, Yayınlanmamış Yüksek Lisans Tezi. Trabzon: Karadeniz Teknik Üniversitesi Fen Bilimleri Enstitüsü, 2003

[25] İ. Genel. Kimyasal Bağlar Konusu İle İlgili Kavram Yanılgılarının Belirlenmesi Ve Bu Yanılgıların Giderilmesi, Yüksek Lisans Tezi. Van: Yüzüncü Y1l Üniversitesi Fen Bilimleri Enstitüsü, 2008.
[26] G. Nicoll. A Report of Undergraduates' Bonding Misconceptions, International Journal of Science Education, 23, 707-730, 2001.

[27] H. Özmen. Üniversite Öğrencilerinin Kimyasal Bağlanma Konusunu Anlama ve Yanılgılarını Gidermelerine Bilgisayar Destekli Öğretimin Etkisi, Milli Eğitim Dergisi, $175,185-197,2007$

[28] D. Kılıç. Analojilerle Öğretim Modelinin 9. Sınıf Öğrencilerinin Kimyasal Bağlar Konusundaki Yanlış Kavramalarının Giderilmesi Üzerine Etkisi, Yüksek Lisans Tezi. Ankara: Gazi Üniversitesi Eğitim Bilimleri Enstitüsü Kimya Eğitimi Bilim Dalı, 2007.

[29] V. Barker \& R. Millar. Students' reasoning about basic chemical thermodynamics and chemical bonding: What changes occur during a context-based post-16 chemistry course? International Journal of Science Education, 22(11), $1171-1200,2000$

[30] J.P. Birk \& M.J. Kurtz. Effect of experience on retention and elimination of misconceptions about molecular structure and bonding. Journal of Chemical Education, 76, 124-128, 1999.

[31] A. Bergqvist, A. Models of Chemical Bonding: Representations Used in School Textbooks and by Teachers and their Relation to Students? Difficulties in Understanding. Dissertation, Karlstad: Karlstad University, 2012.

[32] R. Lee \& M. M. Cheng. The Relationship between Teaching and Learning of Chemical Bonding and Structures. In Topics and Trends in Current Science Education, edited by C. Bruguière, A. Tiberghien and P. Clément, 403-417. Dordrecht: Springer, 2014.

[33] J.H. MacMillan \& S. Schumacher. Research in education: Evidence-based inquiry (7th Edition). London: Pearson, 2010.

[34] A. Yıldırım \& H. Şimşek. Sosyal Bilimlerde Nitel Araştırma Yöntemleri, 7. Baskı, Ankara: Seçkin Yayıncılık, 2008.

[35] R. Bogdan \& S.K. Biklen. Qualitative research for education: an introduction to theory and methods. Boston: Allyn and Bacon, 1998.

[36] J.P. Goetz \& M.D. LeCompte. Ethnography and Qualitative Design in Educational Research, Second Edition, New York: Academic Press, 1984.

[37] M.Q. Patton. How to use qualitative methods in evaluation. Newbury Park, CA: Sage, 1987.

[38] Online Available: Science Teacher Competency, Online available from http://oygm.meb.gov.tr/meb_iys_dosyalar/2017_11/061601 43 3-YYretmen Yeterlikleri KitabY fen ve teknoloji Y Yretmeni_Yzel_alan yeterlikleri_ilkYYYretim_parYa_6.pdf

[39] M. Grosbois, G. Ricco \& R. Sirota. Du laboratoire à la classe le parcours du savoir. Etude de la transposition didactique du concept de respiration. Paris: ADAPT, 1992.

[40] M. Yıldırım. İlköğretim Fen ve Teknoloji Dersinde Genetik Ünitesinin Bilimsel Bilgilerden Öğretmen Bilgilerine Geçişinin "Didaktiksel Dönüşüm Teorisi”" Yaklaşımıyla Değerlendirilmesi, Yayınlanmamıș Doktora Tezi. Marmara Üniversitesi, Eğitim Bilimleri Enstitüsü, 2008.

[41] A. Saracaloğlu \& B. Aydoğdu Fen ve Teknoloji 
Öğretmenlerinin Kișilerarası Öz-Yeterlik İnançlarının Bazı Değişkenler Açısından İncelenmesi, International Journal of New Trends in Arts, Sports \& Science Education , 1(1), 21-35, 2012.

[42] F. Önen \& Öztuna A. Fen Bilgisi ve Matematik Öğretmenlerinin Öz Yeterlik Duygusunun Belirlenmesi,
Yeditepe Üniversitesi Eğitim Fakültesi E Dergisi, 1(1), 1-13, 2006.

[43] A. Saracaloğlu \& N. Yenice. Fen Bilgisi ve Sınıf Öğretmenlerinin Öz-Yeterlik İnançlarının Bazı Değişkenler Açısından İncelenmesi, Eğitimde Kuram ve Uygulama, 5(2), 244-260, 2009. 